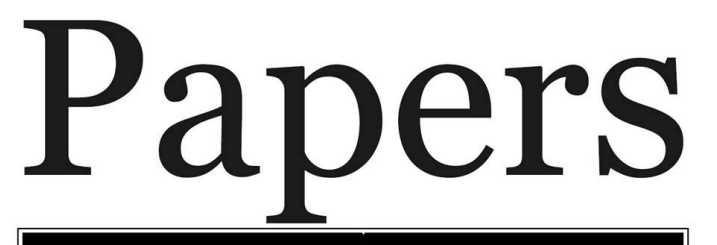

Explorations into Children's Literature

\title{
From the Personal to the Political, Religious, and a Vision of Socialism in Maurice Gee's Orchard Street, a New Zealand Novel for Children
}

\author{
Dr. Vivien van Rij - Victoria University of Wellington
}

\begin{abstract}
This article considers Orchard Street, a novel for children by award-winning New Zealand author, Maurice Gee, and his use of history in depicting New Zealand during the 1951 conflict between the Waterside Workers, and the ship-owners and National government. The article focuses first on Gee's childhood during the 1940s in Henderson, West Auckland, and on Newington Road where he and his family lived as a model for the creation of Orchard Street. It then looks at the integration of the 1951 conflict into this realistic setting, and Gee's charging of the street with a political significance.

A self-proclaimed socialist, Gee is firmly on the side of the Wharfies, as is his protagonist, the thirteen-yearold Ossie Dye who is on the brink of adulthood, and faced with difficult choices. While supporting his parents' socialist ideals, and delivering illegal propaganda at night, Ossie imagines he is the solitary American cowboy, Zane Grey's Lone Star Ranger (p. 13), and excludes the lonely Bike Pike from his gang of friends.

The article briefly examines Gee's use of an older Ossie as the first person narrator who, looking back from 1991 to the 1951 conflict, forms a circular frame that modifies its depiction. Also considered is the influence of neo-liberalism and the social and political reforms of the 1980s-1990s on Gee's writing. The article finally argues that the multi-layered timeframe and geometrical structure of the novel are evidence not only of the author's preoccupation with division but, more predominantly, of his socialist ideology and search for wholeness and balance.
\end{abstract}

Keywords: New Zealand history, socialism, unionism, nationalism

\section{Introduction}

Award-winning writer, Maurice Gee, is widely renowned for his novels for adults, and in the opinion of many is New Zealand's most distinguished living novelist. In particular, the three fantasy novels - The Halfmen of O (1982), The Priests of Ferris (1984) and Motherstone 
(1985) - have ensured Gee a place in the hearts and minds of children, parents, and teachers. Often overlooked, Gee's five realistic historical novels written after the $\mathrm{O}$ trilogy are equally commendable, but for different reasons. As Louise Clark has pointed out, 'they are closer to Gee's novels for adults in content and style' (Clark in Hale 2013, p. 125), thus comprising writing described by Gee as 'vertical' (Gee 2002, p. 18). The realist novels explore issues in more depth and in ways that are often implicit while allowing for the more 'serious exploration of character', a trait missing in the fantasies (Manhire 1986, p. 11). Rather than binaries, however, the fantasy and realist novels can be considered as mixed antitheses. Where protagonists in the fantasy novels occupy obviously symbolic roles during the almost palpable exploration of serious concerns about the real world's environment, society and politics, protagonists in the historical novels are realistically complex and involved in environmental, social and political issues, while having a less obvious but nevertheless important symbolic function. As Claire Matthewson argues, 'In the traditional area of literary realism [ . . ] ], those works which imbue critical history with symbolic tenor, an experiential/significant focus co-exists. [ . . . ] It lies behind the ordinary and within the reader's apprehension of historical pattern' (Matthewson 1986, p. 4). It is the realist dimension of Gee's historical fiction for children, and the symbolic dimension underpinning it that I intend to explore in this article.

In the historical novels Gee creates 'a moralscape' (Hebley in Hale 2013, p. 55) that operates on both personal and political levels, and that encourages the reader to consider the actions and values of characters within the broader context of society. Indeed, Gee, a selfproclaimed socialist, looks back from an era of sweeping revolution that began in 1984 (ironically under a Labour government), and continued through the 1990s (under a National government), to recall his childhood and a lost world - one whose national pride, full employment, largely unionised workforce, communitarian ethic, and social cohesion was replaced by neo-conservative social values and systems of governance, a global economy, and an individualistic ethic. In setting his five realist novels during key episodes in New Zealand's history, Gee explores step by step what has been gained and lost over time, and the influence of social and political conflict on New Zealand lives, particularly those of his 
progressively older protagonists and their families. The Fire-Raiser (1986), an adventure story in the style of Enid Blyton, considers racism, aggression, and mental instability in New Zealand during World War I. The Fat Man (1994), a psychological thriller, focuses on mental instability, bullying, and the influence of the 1930s' Depression. The Champion (1989), a romantic comedy, portrays racism, hero-worship, partisanship, and a young boy's perception of life during World War II. Orchard Street (1998), a rites of passage story, looks at the impact of the Cold War on New Zealand society, and the lockout in 1951 of waterside workers by the National government. And finally, Hostel Girl (1999), a psychological thriller in the noir genre, set in 1955, depicts predation and adolescent romance within the context of the counter-culture movement, including its strands of feminism, American popular culture, and youth revolt.

It is on Orchard Street, the most purposely political of Gee's realistic novels, that this article focuses in order to explore ways in which, reacting against the conservative political period from which he is writing, Gee recalls an earlier conservative period, and in fictionalising his childhood hometown of Henderson and its inhabitants, conveys a vision of socialism that more closely equates to his adult ideology. Like The Fat Man and The Champion, Orchard Street is set in Henderson, West Auckland, and is a coming of age story in which protagonists demonstrate on a personal level the political and social conflicts that exist in the wider world (see van Rij 2008, and van Rij in Hale 2013). However, it differs from the first two novels whose protagonists experience politics indirectly in that its protagonist and his family are actively involved in political conflict and, moreover, are confronted by characters of diverse spiritual beliefs. As I shall argue, during the course of the novel's depiction of a realistic world and a personal story, Orchard Street itself becomes emblematic not only of the protagonist's inner journey from innocence to morality, and from right wing individualism to left wing altruism, but also of New Zealand's 'awakening imagination', a term used by William Oliver to describe the flourishing of the arts and liberal humanist movements following the end of World War II (1981, pp. 430-461). As Carlyon and Morrow have noted, between 1945 and 1965, New Zealand moved increasingly away from 'maternal folds' (2013, p. 45) in its struggle for a distinct national, cultural and spiritual identity. Gee himself was a 
product of that era, and in his fiction for children (as in his fiction for adults), echoes not only its hatred of war, entrenched conservatism, and cultural imperialism, but also its celebration of peace, the New Zealand landscape, and the New Zealand human environment on both particular and universal levels (Oliver 1981, pp. 455). It is therefore the complex 'moralscape' of the protagonist and of the New Zealand identity that the novel explores in its depiction of a particular street, and that I consider in this article.

Orchard Street is told retrospectively from the point of view of the adult Austin Dye (nicknamed Dinky or Ossie) who in recalling 1951 (when he was aged about fourteen) and the Waterside Workers' dispute with the ship owners over higher pay, provides the bulk of the novel. He describes their lockout from the waterfront by National Prime Minister, Sidney Holland, and their attempt to subvert the Emergency Regulations, a set of laws rushed through parliament which allowed police unwarranted power (Gee 1998, p. 10). Born in 1931, Gee would have been about sixty-seven in 1998 when writing the novel, and about twenty in 1951 when the book is mostly set. What we are given in Orchard Street, then, is a conflation of his memories of childhood in 1944, the politics of 1951, the personal twist he gives things in recalling these periods, and his socialist stance as an older author in 1998. Emerging from the novel, Gee's socialist vision encompasses the trade union movement, its close ties with the Labour Party (a coalition with options that include Social Democracy and Communism), and notions of equality, fraternity, solidarity, co-operation, altruism and the collective. Hence, the novel and its historical contexts are interwoven to become emblematic of Gee's political beliefs, while its depiction of unstable times is counterbalanced by Gee's concern not only with a society that is socially, politically and spiritually divided, but also with constructing a novel that is balanced, cohesive, and whole. I turn now to examine in chronological order the novel's multiple timeframes, starting with Gee's childhood and the novel's personal dimension.

\section{Small-town New Zealand in the 1940s}

Gee's novels have 'drawn the landscapes of New Zealand's provincial towns and middleclass suburbs with [ . . . ] the fidelity of a Balzac' (Barrowman 2015, p. 1). So specific are 
descriptions of Orchard Street in which Ossie and his family live, that connections to Newington Road, Henderson (23 kilometres west of Auckland), in which the Gee family lived in the 1940s are obvious, as has been demonstrated by the author's exploration of the road, interviews with two of its elderly residents, and Gee's own recollections on which the following account has been based (see interviews 2005; Gee, 1977, pp. 284-92).

Running north to south, Newington Road has higher eastern and lower western sides, and in 1944 had a turn-around (or blind end) since initially it was developed by the Railways from opposite ends, with farmland cutting across the middle. However, the ends were joined in 1947 , with sections occupied by 1920 s to 1940 s style houses being numbered in 1960 . The bungalow on the south western corner at number 61A, belonged to Gee's friend, Murray, whose father drank poison and died, while the bungalow at number 55 was inhabited by the elderly Harts whom the young Gee used to visit to play drafts and chess, and borrow novels by Zane Grey and Charles Dickens. Further along stand several railway cottages. Number 51 belonged initially to Mr Flynn, an engine driver (who was notorious for beating his sons), and his wife, and later to the Kayes who believed in Radiant Living (a new age religion imported from America). Next door at number 49 dwelt the Scotts. Mr Scott, a chemist, kept budgies and once made a huge kite that broke when he tried to fly it. In number 47, another railway cottage, resided the Greenough family with Stan Greenough working first for the Railways as a shunter and a signalman, and second as a florist, while son Gordon was a lonely only child.

A dip marks the area which once was Newington Road's turn-around and which comprised farmland owned by a Northern Irish family, the Donohies. Then on the road's eastern side at number 50, on land formerly owned by the Gees, Mr Verijt lived in a shed. Next-door at number 52 was the Gee family's home, a modest wooden bungalow with a view beyond the road's west side, to the distant Waitakere mountains. Gee's family was Labour and Pacifist. His mother, Lyndahl, with her hair plaited around her head and long clothing, was oldfashioned and did not mix socially while his father, Len, was tall, fine looking and friendly. A builder and a boxer, he had part ownership of a racehorse, and placed bets with Norcross (a local bookie), whose home was raided by police during the 1951 watersiders' lockout. Next 
to the Gees at number 54 resided a childless couple, Mr Pinkney and his wife (the Harts' adopted daughter) who were the only National Party members in the street with Mrs Pinkney wearing a blue dress on election day.

Memories also suggest the disjunction between the personal and public. The Pinkneys might have been right wing, but during World War II they made tents for workers. The Gees might have been Labour, but it was Len who was sociable while Lyndahl was aloof. Similarly, Gee's recollection of how he and his brothers spied on nuns walking in the Catholic School's yard behind their section, and of brother Gareth, an armed bank junior who slept over for security, suggests their aggression. Indeed, another bank junior, mistaking a friend climbing through a window for a burglar, shot and killed him. Additionally, Gee has noted that he and a friend made a 'two man purity squad that patrolled the [school] playground for bad language and improper behaviour', and that he was a 'most horrible little prig'. Gee thus suggests the 'despair and confusion under the simple, uncomplicated New Zealand surface' (Barrowman 2015, pp. 19, 13), as well as the puritanism that sometimes overlays it.

\section{The Presence of Newington Road, 1944, in Orchard Street, 1951}

Orchard Street precisely reproduces Newington Road's topography. The street has higher and lower sides - Ossie proceeds uphill to his, or his next-door neighbours' homes, and downhill when visiting neighbours living opposite. Recalling the real Waitakere mountains in the distant west, observable from the Gees' property, the fictional Waitakere mountains are observable from the Dyes' property, confirming again Orchard Street's higher eastern and lower western sides.

Similarly, fictional characters resemble people from Gee's past. Ossie's visits to old Mr Worley across the road to play drafts and chess, and borrow novels by Grey and Dickens, recall the young Gee's visits to old Mr Hart living across from the Gees. Likewise, the outcast Bike, the only child of the Pikes living opposite the Dyes, evokes the lonely Gordon Greenough and his family who lived opposite the Gees. And the novel's childless couple, the Redknapps, who reside next-door to the Dyes, and make tents for workers, resemble the 
childless Pinkneys, the Gees' next-door neighbours who made tents for workers. Most obviously, the Labour and Pacifist Dye family recalls the Labour and Pacifist Gee family. The father, Eddie, is sociable and places bets on horses, the mother, Lil, is 'a snob' (p. 15), Ossie's brother, Les, works in a bank as an armed security guard, and lives in a shed resembling $\mathrm{Mr}$ Verijt's, and Ossie hides in the pine trees at the back of the Dyes' section and spies on nuns. In drawing on his childhood, and writing in the first person Gee creates a convincingly realistic child's perspective of characters and events.

However, Gee changes his childhood world in Orchard Street to reflect his interest in conflict and division. Thus, his renaming of the Nationalist Pinkneys as the Redknapps suggests they are socialists. In Murray's house at Newington Road's south-western end, he installs the bruised Mrs Cooper, a victim of her husband's brutality, while Mr Worley, a conservative and capitalist, enlarges on Mr Hart's conservatism. And by fusing elements of the Kaye, Flynn, Scott and Greenough families Gee creates the Pike and Raffills families, with the former, like the Kayes, believing in Radiant Living. Also recalling the brutal Mr Flynn, Mr Pike is aggressive, Mr Raffills beats his sons with a tomato stake, and Mr Scott's attempt to fly a kite is echoed when Mr Pike does the same. Additionally, Gee replaces the Northern Irish Donohies living at Newington Road's blind end with the Irish Catholic Collymores who live at Orchard Street's blind end.

On the street's eastern side, then, the Dyes and the Redknapps are socialists, on the western side the Coopers, Worley, Pikes and Raffills are conservative or quasi-fascist, and the blind end the Catholic Collymores are politically neither one thing nor the other, with Frank (the father) having 'no interest in union affairs - union hoo-ha, he [calls] it' (p. 33) - but equally uncommitted to nationalism, or to anything except his wayward desires which include womanising.

However, Gee is too good an author to portray characters as one dimensional. As we have seen, his memories reveal contradictions between the personal and public, and it is on these that he builds in order to provide a rounded picture in writing the novel. Hence, the 
conservatism or aggression characterising those living on Orchard Street's western side is offset by their generosity. Mr Worley adopts Ossie's dog when Ossie no longer wants him and, unlike his aggressive father, Bike Pike is gentle, graceful and friendly. On the street's socialist east side Mrs Redknapp is unsociable, the snobbish Lil Dye '[likes] people who speak well and [remember] their manners' (p. 13), and the unruly Les dresses in black to graffiti the town while his shed is termed 'the army hut' (p. 64). And at the blind end, in contrast to her dissolute father, Ossie's girlfriend, Theresa Collymore, is loyal and passionate. At 'going on fourteen' (p. 23), Ossie is midway between childhood and adulthood, and is as divided as others in Orchard Street. As we shall see, his pull between a personal agenda and social responsibility has political implications.

\section{New Zealand Politics in 1951}

Gee invests his memories of childhood in the 1940s with a larger political significance by bringing into the novel figures of 1951's post-war climate of extreme nationalism. These include Prime Minister, Sidney Holland, whose National government embraced capitalism and the Anglo-American free market (Mein Smith 2005, pp. 213-14), and whose opponents named his government 'Sid Holland's new private enterprise party' (Yska in Grant 2004, p. 25). In bowing to Great Britain and America whose dollar he courted, Holland was seen as 'a puppet' (Phillips in Grant 2004, pp. 170-71), while many viewed his Anglo-American capitalism as a betrayal of New Zealand's working classes (Andersen in Grant 2004, p. 115).

It was under the 1951 Holland government that New Zealand joined ANZUS (the defence pact with Australia and America), and increasingly adopted America's Cold War McCarthyism which ensured the persecution of Communists. Permeating New Zealand life, this mentality became confused with the waterfront dispute, a fact exploited by the government in order to gain popular support (Mein Smith 2005, p. 181). Indeed, the FOL (Federation of Labour) 'denounced the strike as an "extension of the Cold War"' (Hunt 2004, p. 144). Waterside workers were labelled communists or Russians, and ship owners and employers (along with Holland) were perceived as loyal to Britain and America, while Holland's Emergency Regulations which were whipped up almost overnight, gave unprecedented power to the 
police and seemed to be an extension of the east/west division under ANZUS. Documenting the lockout, Dick Smith termed the regulations a 'fascist blueprint' (Scott 1954, p. 14), and quoted the clause forbidding support of strikers and promoting the power of police:

\begin{abstract}
Any person who carries, displays, drives or causes to be driven any vehicle carrying or displaying or fixing in any place where it is in sight of any other person, any banner, placard, sign or any other thing, writes, prints or causes to be written or printed or displayed on any vehicle, wall, fence, erection, road, street or footway or otherwise in sight of any other person, can be arrested without warrant by any constable, and every vehicle and any property can be seized immediately by that constable. (Scott in Grant 2004, pp. 30-31)
\end{abstract}

Many on the left saw aspects of Holland's government as a version of World War II. Indeed, 'fascism or German Nazism became the definition of a political evil [while] Holland's radio appearances were likened to Hitler's' (Phillips in Grant 2004, p. 171). Most notorious were the remarks during parliamentary debate of William Goosman (Minister of Railways) who promoted Hitler's ideology:

Goosman: The instigators of the (waterfront) trouble are anti New Zealand and anti-British - they are worse than transferable diseases and we have to take steps to deal with them.

McCombs: Hitler talked the same way.

Goosman: All I have to say is that if Hitler had to deal with the same thing, Hitler talked right. (Scott 1954, p. 49)

Newspapers and the radio, on the other hand, described the watersiders as communists, thugs, beasts, and wreckers. Acknowledging the blanket of silence and fear, Scott has recalled how he and fellow communists, writer Chip Bailey, and cartoonist Max Bollinger, resorted to analogy and allegory to voice their beliefs. A verse published anonymously at the time is an example of this inventiveness: 
Sid's trip to the moon

King Sid lay back with a contented sigh,

Everything on the waterfront was lovely.

He rang for his fiddlers three $[\ldots]$.

In trouped the Black Prince

With his tame parrot

Who keeps screaming they're all communists.

Lord Scabaxter with his Doubled Cross Charts,

And little Bill who as everyone knows

Is worth his weight in gold. (Anonymous 1951)

The verse's parody of the English nursery rhyme, 'Old King Cole', emphasises National's affiliation to Great Britain, the monarchy, and the heavy-weight capitalists. 'King Sid', 'the Black Prince', 'Lord Scabaxter', and 'little Bill' refer respectively to Sid Holland (Prime Minister), Fintan Patrick Walsh (Vice President and later President of the FOL), Ken Baxter (Secretary), and William Sullivan (Minister of Labour, nicknamed Big Bill), with the term 'Scabaxter' suggesting Baxter's disloyalty (Bassett 1972, pp. 256-64). 'Scabbing' (derived from the noun 'scab') refers to those disloyal to the left, whose names were published on a flat beer list or roll of dishonour as a mark of shame, while the tame parrot alludes to those squawking the party line. Different again, Labour leader Walter Nash was notorious for refusing to take sides, as his comment at a TUC rally confirmed: 'We are not for the watersiders, and we are not against them' (Hunt 2004, p. 159).

Most hated of scabs was Fintan Patrick Walsh. Born Patrick Tuohy in 1894 to a large Irish Catholic family, he repeatedly changed his name and political affiliations, becoming involved in Chicago's gangster world in 1915, then a member of Sinn Fein and the IRA, and joining New Zealand's Communist Party in 1920. Labelled a Marxist bully boy, and acquiring the moniker Black Prince, Walsh worked on the waterfront, joined the union, and eventually became a member of the FOL. Exercising mafia-like tactics, he was known as the Muscle 
Man of Labour Prime Minister, Peter Fraser, and when National came to power, as Holland's henchman, with an aggressive control of unionists (Hunt 2004).

As historical accounts of the 1951 lockout tell us, the watersiders' union was internationalist and was led by President Jock Barnes (a former wharfie, with a history of militant unionism, and known as 'the Strawberry Bull') and National Secretary, Toby Hill. The group's great strength was its unity in the face of adversity (Barnes 1998, p. 14). Indeed, a common symbol of the union's internationalist and socialist ideals was that of workers clasping hands across the globe, an example of which can be seen on the New Zealand Waterside Workers' loyalty certificate (see Scott 2004, p. 161).

Whole families participated in the illegal printing and delivery of union leaflets. Scott has recorded: 'The frightening thing about 1951 was that it was a pure police state. [ . . . ] Chip, Max and I never used the phone because you had to operate it as though you were in a Nazioccupied territory' (Scott in Grant 2004, pp. 30-31). Chip Bailey's wife, Rona, has recalled hiding their typewriter in a space above the pantry covered with a panel of wood: 'Copying bulletins and leaflets was a logistical nightmare. We carried the Gestetner around from place to place'. The supreme power given to the police meant they could raid homes three or four times a night as Rona Bailey has noted when 'two hefty policemen', Dave Patterson and Detective Knapp, entered her home unannounced. Delivery of the pamphlets was equally hazardous. Bailey would load up her car and take pamphlets to the Trades Hall in Courtenay Place, Wellington where they were secretly distributed to the watersiders (Bailey in Grant 2004, pp. 41-43). For Sandra Lee whose family spanned three generations of waterside workers, delivery was a family matter:

One evening my dad, along with my mum's brother Cyril, were distributing illegal union leaflets down by the railway station when they were spotted by police who gave chase. My father was fast on his feet and he carried out a diversionary tactic so Cyril could escape. (Lee in Grant 2004, p. 127) 
Violence under the Emergency Regulations was sanctioned. On 2 May 1951 over one thousand watersiders, seamen, and freezing workers marched from Wellington's Trades Hall to Parliament to try to convince Holland to re-open negotiations only to be attacked by police on the corner of Cuba and Dixon Streets. Further violence occurred during a gathering in the square outside Auckland's Chief Post Office on 18 May, as Barnes has recalled:

While we were peacefully talking, the SS charged with batons flying. Some of the older police acted moderately and fairly, but many of the younger ones relished their unbridled power and acted like the legalised thugs they were. Those of us still standing were kicked, bashed and punched from the Central Post Office to Milne and Choyce. [ . . . ] An 81-year-old man, walking with the aid of a stick, was bashed and kicked for good measure. [ . . . ] All that were missing from the scene were the jackboots and swastika armbands. (Barnes 1998, pp. 204-5)

Even worse was the march of 'Bloody Friday' on 1 June which involved about one thousand watersiders and supporters who proceeded from Auckland's Queen Street towards Myers Park, where police rushed them, striking indiscriminately with their batons. In late May, at a meeting in Auckland's Town Hall, Barnes had launched a verbal attack on the policeman who assaulted the elderly man earlier that month. For this, on 7 July, Barnes was charged with 'criminal defamation' and jailed. His case was heard in August when he was found guilty and sentenced to two months' hard labour. On 12 September the final figures came in for a snap election called by Holland. They ensured National's return to government, the dismissal of an appeal by Barnes, and a victory against watersiders who between 7 June and 16 July gradually returned to work (Barnes 1998, pp. 227-29).

\section{The Presence of New Zealand Politics, 1951, in Orchard Street}

Into the small, self-absorbed world of Orchard Street Gee brings the larger, fractured world of New Zealand politics, 1951. Merging memories of his childhood in the 1940s with explicit historical detail of the early 1950s, Gee reveals Ossie's thoughts about the lockout and Emergency Regulations: 
I'll have to write a little bit of history after all. When the wharfies and the shipowners disagreed - it was over wages and hours of work - the bosses locked the men out. No doubt about that. But [ . . . ] Sid Holland's government pretended it was really a strike and set about destroying the Waterside Workers' Union. It was run by communists, they claimed. (Dad never denied it.) They brought in a set of emergency regulations which said, among other things, that anyone printing a pamphlet aiding or abetting the strike was committing an offence. The police could come searching without a warrant, using force if they thought they had to, and no claim could be made for any damage or injury they caused. (p. 10)

Authenticating historical accounts such as Scott's (2004, p. 161), Gee's fictional account includes in Chapter 1 an exact copy of the Watersider Workers' Loyalty Certificate which names allied groups including seamen, miners, and freezing workers on each side, and which includes at the top an image of two men involved in co-operative work. Signed by Jock Barnes and Toby Hill, it also displays the workers' symbol of unity - two hands clasping across the globe (p. 8).

In capturing the public perceptions characterising the times, Gee reveals his dislike of capitalism and support of unionism. As Ossie observes in Chapter 5: 'The newspapers [... ] printed speeches by politicians calling [the wharfies] greedy loafers and wild beasts, calling them savage and filthy and foul. They needed a good clout with a baton, one shipowner said. [... ] And the wharfies' pamphlets said things just as bad about the politicians and the scabs and the police' (p. 51). Holland's affiliation to the wealthy ship owners becomes explicit when Ossie reads a wharfies' pamphlet: 'The Holland government is starving our families [and the] ship owners [who are] sucking fat cigars [are telling their workers to] work 59 hours a week or [they] are dumped' (p. 13). 
Holland's aggressiveness is emphasised with Eddie Dye comparing the battle between him and the watersiders to 'fighting Hitler', and the 'new regulations' to 'those in a fascist country' (pp. 10-11). Likewise, Holland's links to Nazism and capitalist Anglo-America, and Gee's dislike of both are recalled in Chapter 10, when the slogan '\$id Holland' (with a swastika in place of the letter ' $\mathrm{H}$ ') is painted on Pike's garage door (p. 95). And referring to Goosman's outrageous claim, Ossie notes that 'when a government minister called Goosman, talking about unions and communists, came out and said, 'Hitler talked right' my poor dad almost cried' (p. 51). Historical events are integrated into the novel's plot. For example, the Dyes print illegal pamphlets:

Dad wasn't a wharfie. He was a printer, but he was an ardent union man. The new regulations were like those in a fascist country, he said. [ . . . ] He had a little print shop under the house. [ . . . ] He made a bit of money in his spare time by printing wedding invitations, twenty-firsts, and flyers advertising bring-and-buys and mock courts. But in 1951, when the lockout began, he started printing leaflets for the wharfies. (p. 11)

Likewise, Rona Bailey's nightmare of hiding her gestetner behind a wooden panel is echoed when Eddie and Lil hide their printer behind a wooden barricade. Exactly as noted by Sandra Lee, the printing and delivery of pamphlets involves whole families. Ossie comments: 'I sided with Dad. It was workers against shipowners, workers against Slippery Sid, but it was a family thing for me. Us against them' (p. 9). Like Lee's father and father's brother, Ossie and Les deliver illegal union leaflets at night while Ossie, having absorbed the prevailing fear, likens them to 'spies in the war, with the Gestapo after them' (p. 12). In fact, Gee integrates actual propaganda into the novel. Lil and Eddie print 'Sid's trip to the moon', with its explicit references to 'the Black Prince', 'Lord Scabaxter', and 'the Tame Parrot' who screams 'They're all communists' (p. 42). And Eddie prints 'the flat beer lists' and 'rolls of dishonour' naming the 'scabs' who have betrayed the wharfies' cause (p. 69). 
Recalling biased reports of the Cuba Street incident on 2 May, Eddie gives an account of the other side's story, echoing what Gee does in writing the novel (and in publishing previously banned propaganda) - he corrects the balance. As Ossie notes:

[Dad] was enthusiastic about doing leaflets that told what the police and the government were up to - describing a fight in Wellington where 10 of the wharfies ended up in hospital. The papers couldn't say what their injuries were - and didn't want to, Dad said, because they were on the bosses' side. Dad's leaflet made it clear that most of the wounds were cuts in the head from police batons. He liked printing that sort of thing to set the balance right. (p. 69)

Similarly, in Chapter 12, Lil recalls Bloody Friday on 1 June, but amends the newspaper's biased account that 'the wharfies were beaten' and that 'evil foreign documents had taken an honest British kick in the pants' to 'a belt on the head with a baton, more like' (p. 111). The setting of this chapter explicitly on 'Saturday [ . . . J July 7, 1951' (p. 121), and its retrospective account, accommodate the return to work of the real miners and seamen from Saturday 7 to Monday 16 July.

\section{The Fusion and Deeper Influence of 1951 Politics and Spiritual Beliefs in Orchard Street} However, Gee gives historical detail a twist. As Tatjana Schaefer has noted, having feared the Catholic nuns during childhood, and growing up with 'the imagery of fascism and the totalitarian threat of Nazi Germany', Gee seemingly sees religion and fascism as equally dangerous, and fuses the two together. Schaefer gives as an example of fusion the priests in The Priests of Ferris who are clothed in black uniforms strongly resembling those of the SS, with their symbol being 'outstretched wings [ . . . ] akin to Nazi Germany's coat of arms'. She adds that, 'by using these visual representations of totalitarian military power in the priests [Gee creates] an overlay of institutional religion and totalitarian political rule' (Schaefer in Jackson et al 2011, pp. 140-141). As we shall see, Gee creates similar overlays of the political and spiritual in Orchard Street. 
Rather than simply replicating history and righting the balance, therefore, Gee has his characters absorb and reproduce traits associated with historical figures, events, and belief systems to become composites of the period's conflicting ideologies. Most interestingly, diverse features concur within a single conflicted fictional character.

On Orchard Street's west side, the capitalists and quasi-fascists are connected to right wing politics to varying degrees. For example, in selling his orchard to a speculator, and giving up the common land which gave the street its name, Mr Worley plays the free market. Even his friendship with Ossie involves direct bargaining when he trades off Grey's novels for playing draughts, at which he likes to win. With an English accent, and having fought for Great Britain as a major during World War I, Worley reflects the diminishing but still potent influence of a class-ridden England. At the same time Mr Worley has pragmatic and humanist principles in that he believes that 'when you do certain things you've got to take the consequences' (p. 137), and draws on the classics, arts, and sciences for his beliefs, thus introducing Ossie to astrology, astronomy, Galileo's mathematical principles, and ancient myth. He therefore makes an important contribution to Ossie's awakening imagination.

More extreme in his demonstration of the capitalist mentality, and an example of the quasifascist politician, is Pike. That the name '\$id Holland' fusing the dollar and swastika signs is painted on Pike's garage, suggests he is Holland's counterpart in Orchard Street, and that he subscribes to American capitalism and individualism. Certainly, Holland's McCarthyism is echoed in Pike's hatred of communism, Barnes, Hill, and Russia when he shouts 'Commie lover' (p. 9) at Eddie Dye, and later states: 'Do you know three things I hate? [ . . ] A communist, a rat, and a communist. [ . . . ] I'd put them up against a wall and shoot them. Starting with Mister Barnes and Mister Hill. [ . . . ] I'd send them to Russia. Barnsky and Hillovitch' (p. 47). As a railway signalman giving directions, and capitalising on death to sell funeral wreaths, Pike embodies the authoritarian, mercenary attitudes of Holland's command economy. Further connected to America through his belief in Radiant Living which promulgates temperance, a natural, healthy, balanced life-style and nutritious diet, Pike ironically is far from radiant, mentally balanced or healthy. Hence his attempt to fly a kite 
and the release of his budgies represent his thwarted desire for transcendence, as do his boils, while his wiring of flowers into funeral wreaths suggests that he is anti-nature. Pike therefore seems to conform to Matthewson's notion of the 'hall-marks of New Zealand conservatism' in that (like Duggie Plumb in Gee's Sole Survivor) he is anti-communist, individualist and anti-intellectual' (1986, p. 136).

Conversely on Orchard Street's east side, the Redknapps sewing tents in their 'workroom' resemble the watersiders, as Ossie observes in Chapter 1: 'Sometimes he had trouble lifting the canvas and she ran to help, shouldering the heavy stuff like a wharfie' (p. 15). But in keeping so closely to themselves, the Redknapps do not demonstrate the socialistic principles of fraternity or community, while Mr Redknapp's belief system contradicts socialism's irreligious stance. That in Chapter $11 \mathrm{Mr}$ Redknapp admits to being a churchgoer (but 'not in a regular way') and to believing in the existence of hell (while noting that 'it's just not where the preachers say') suggests, in fact, that he is an agnostic (pp. 106-107).

Next door to Rednapp, Lil Dye is similarly complex. Humanist in her pronounced beliefs, Lil rejects Christianity. As Ossie says in Chapter 3: 'One of the things she held against Frank Collymore was that he was a Catholic. We, the Dyes, didn't have a religion. You didn't need one, Mum said, to be a good person. "Say you're nothing, if anyone asks. Say you believe in the human race"' (p. 34). However, in Chapter 11 (entitled 'Poetry'), Lil contradicts her earlier statements. After rejecting 'grace' she goes on to say that thanks is, indeed, required: 'We think that enjoying food is thanks enough' (p. 105). Then, admitting to crossing her fingers whenever grace is said, she effectively acknowledges its power. And by quoting the third line from Robert Browning's poem, 'Rabbi Ben Ezra' ('The last of life for which the first was made' (p. 107)), she confirms the Christian belief in an afterlife.

At the same time, Lil and Eddie on Orchard Street's east side play their parts in the novel's historical dimension. In loyally assisting Eddie's printing of propaganda, Lil recalls the socialist Rona Bailey, while Eddie conflates traits of Chip Bailey, her husband the printer, and 
Jock Barnes the union leader. That Eddie is jailed for his underground activities on Saturday 7 July, 1951 - the exact date that Barnes was charged and jailed - confirms their parallel.

Hence, Gee depicts characters that on a larger level occupy historical roles, but that on a personal level are politically, socially, and spiritually mixed. Their complexity is emphasised by the underpinning of their overt political and religious beliefs with various contradictory forms of disloyalty and exclusion throughout the street. Those on the west side may be right wing but they are divided against themselves. Mr Cooper has beaten his wife, but it is she who scabs by eloping with a house painter. Mr Raffills beats his sons, but they and his wife lock him out of the house. Recalling the aggressive Barnes (the strawberry bull), Raffills roars 'like a bull and [bangs] on the walls' (p. 160). And although terming communists and their supporters 'our red friends [ . . . ] a pack of villains' (p. 71), Mr Worley resembles Nash in that he refuses to take sides, as he tells Ossie: 'You should be like Mr Nash, neither for nor against. [ . . . ] Both lots are a pack of scoundrels, Holland and Barnes' (p. 72).

The socialists on the east side are equally divided. In working in a bank, and aiming to become an employer, Les qualifies as a capitalist. That he lovingly wields his revolver, and dresses in black to graffiti the town, recalls the thug-like Walsh, the Black Prince. Ossie, on the other hand, resembles the tame parrot who squawks the party line: “"[Dad] says guns are for lunatics. And uniforms too. And all that saluting and stuff. [ . . . ] He just wants to fight with common sense," I said. [Mr Redknapp and Mr Worley] laughed knowing I was a parrot' (p. 72). Moreover, seeking to impress Theresa by showing her the Dyes' hidden typewriter, Ossie betrays his family. In Chapter 12, recalling the police raid on Bailey's house and the raid in 1951 on Len Gee's bookie friend, Norcross, the police raid on the Dyes' house is directly attributable to Ossie's betrayal.

Orchard Street's topography therefore emphasises its mixed social, political, and spiritual sides. When socialists living on the higher eastern side want human company they cross to the lower western side, as Ossie does when visiting Mr Worley to play games and borrow books. When the conservatives and quasi-fascists living on the lower western side want to 
transcend the human condition they cross to the higher eastern side, as Mr Pike does when flying his kite on the farmland behind the Dyes' house. And the street's turn-around or blind end is emblematic of ignorance and a refusal to take sides, with Frank Collymore's ironic lack of frankness, betrayal of his wife, and blindness to her suffering, representative of his lack of commitment to any belief system, social, political, or religious. Gee thus emphasises the street's circularity and divisions, and its function as a representation of the whole. In crossing the street from side to side, in venturing north to its blind end, and in circling back down to the south and around, Ossie comprises an all-seeing eye that conveys the broad spectrum of its conflicts to the reader, even if he does not understand them himself. Emerging from the small personal world of Orchard Street, therefore, is the notion of the collective New Zealand identity, including its conflicting social, political, and spiritual ideologies in 1951.

\section{Ossie's Cold War}

So closely does Gee fuse the personal, social and political that they become inseparable. He suggests that the socio-political climate is responsible for characters' instability, and that conversely characters' instability contributes to the socio-political climate. On the one hand, Gee depicts Ossie as a romantic loner, distinct and unique, with free will. On the other hand, Gee's interweaving of the personal and political, and the street's mixed antitheses emphasises Ossie as an integral part of the whole, and to a degree accountable to it, and responsible for it. Within this complex 'moralscape' the lone individual represents a stage of immaturity, while the socialised individual who not only sees, but imagines, and empathises, moves towards wisdom. Gee therefore positions Ossie at the centre of a warring world that is mirrored within him, and subjects him to rites of passage that chart his movement from innocence to experience.

Ossie's name has political connotations. A colloquial term for socialist East Berliners during the Cold War, 'Ossie' is also an abbreviated version of the young Gee's nickname, 'Mossie', while the homophonic 'Dye' possibly suggests mortality. However, recalling the young Gee's obsession with Zane Grey, and his two-man purity squad, Ossie seeks imaginative 
transcendence of social and human factors. In Chapter 1, delivering the wharfies' pamphlets, he romanticises himself as the outcast cowboy hero of Grey's The Lone Star Ranger and the street as the landscape of American western. Similarly, his obsession with Jupiter, which he observes one night through Redknapp's telescope, embodies his yearning for distance, purity and power. Ossie records: 'My eyes came right and the planet was there, filling the lens - invading me, Jupiter. At first I gasped, then I held my breath. To tell the truth, I felt like crying. I'd never seen anything so beautiful before'. As Redknapp tells him, Jupiter is 'a gas giant [ . . . ] bigger than a thousand moons' (pp. 17-18) and, indeed, Ossie notes that Jupiter is 'the king of the gods' (p. 96). Thus Jupiter represents Oliver's 'awakening imagination', not only that of Ossie, but also of those in the street who aspire to a life beyond the everyday. The novel's most dominant symbol of imaginative transcendence and purity, Jupiter reflects above in macrocosm what exists in microcosm in its ironic opposite below: Orchard Street and its depressed and fractured society.

However, Gee does not allow the symbolic to govern the realistic. As Matthewson has argued, it is with the personal, particular and specific that Gee is more concerned, rather than the general, the philosophical, or the metaphorical and, if the latter emerge rather than being the main focus, or are extrapolated by the reader to convey a sense of the spirit of the age, then that, as Gee has put it, is 'a bonus' (Matthewson 1986, pp. 141-145). Thus, the main emphasis of the novel is on the everyday world of a particular street named Orchard and its inhabitants. While Ossie may idealise the Lone Star Ranger and Jupiter as representations of invincibility and purity, in doing so he locks the particular, especially human imperfection, out of his consciousness, thus effectively waging a Cold War on himself and others. When spying on the fallible Redknapps, he feels discomfort at their emotional and physical frailty:

Once he had a coughing fit and she held his head on her huge breast until it was done. [ . . . A And once when she stood in the roses, crying silently, he came out of the house and dried her eyes with his handkerchief. [ . . . ] It seemed all wrong 
to me that people as old as the Redknapps, and fat and thin, and sick as well, should behave like that. It made them ridiculous, and it troubled me. (p. 15)

Similarly, Ossie's callous description of Mrs Redknapp 'as loose as sand inside her silly dress [and] mad' (p. 26), suggests her mental instability and, in its mixed idioms, his limitations. At the same time, Ossie's words comment ironically on the unstable politics of the street and times.

Ossie's dog, Jimpy, allows him some understanding of suffering. Set in ironic contrast to Jupiter, the 'zebra striped' (p. 18) gaseous super power of Chapter 1, Jimpy in Chapter 2 is old, grey and gaseous (he emits bad smells), thus demonstrating the mortality Ossie fears. Where Ossie in effect colonises Jupiter who '[fills] his half-dreams' (p. 19), he relinquishes Jimpy because he cannot keep up with him. In giving his dog to Mr Worley, and scabbing on a family member, Ossie is responsible for Jimpy's death when, seeking to return to home, he is run over by a drunken Frank Collymore. But in Chapter 7, with the night-time drizzle emblematic of his misery, Ossie returns the dead dog to Mr Worley. Experiencing death personally, Ossie now not only sees, but imagines and thus feels Mr Worley's similar sadness and, in apologising, takes responsibility for it.

A further rite involves Ossie and the eccentric Bike. Representative of the street's mixed antitheses, they have much in common. Not only is Ossie's scorn at Bike's 'mixing of his idioms' in describing Mrs Redknapp as being 'as nutty as a two bob watch' (p. 26) ironic in that he too has mixed his idioms, but also Ossie has earlier been in love with Eileen Collymore (Teresa's older sister and Bike's current romantic interest). In Chapter 8 , in a moment of insight, Ossie sees Bike's fragmentation, and its projection onto the surrounding scene: '[Bike] was standing by a tree inside his gate. The street lamp lit half his face and made a long shadow that broke in the centre and climbed the garage wall' (p. 83). However, Ossie fails to empathise with the fragile Bike and freezes him out of his thoughts and circle of friends. Lacking consciousness of their shared traits, and the interwoven nature of the lives on Orchard Street, Ossie is partly responsible for Bike's subsequent breakdown. 
In Chapter 13, Bike's ascent of the pine tree at the back of the Dyes' section on Orchard Street's higher eastern side in order to shoot Les, and his accidental shooting of Eileen, recalls Gee's memory of the bank junior that killed a trespasser. But Gee resists making an 'imaginative leap' or playing with history. Rather, he remains faithful to the historical fact that no-one during the waterside dispute lost his or her life as a result (Matthewson 1986, p. 16), and instead downplays the situation to emphasise its ordinariness and particularity. Where in his adult novel Sole Survivor (which also depicts the 1951 lockout), he casts Raymond Sole (the first person narrator) in the role of cynical journalist, thus allowing him explicitly and self-mockingly to undercut his own attempts at heroism (Matthewson 1986, p. 122), in Orchard Street he has Ossie as the naïve first person narrator and observer of characters and events, unwittingly noting their mundanity. The pine tree episode therefore comprises a version of warring super powers that is bathetic, while characters are thrust into mixed versions of political roles that are ironic. For example, Bike's gun, a Smith and Wesson (an American brand), and his anger align him to American and Nazi fascism, his red clothing associates him with socialism, and his perch alone in the chilly night air high on the pine positions him as an outcast in a Cold War. At the same time, Bike's derangement, and his 'mouth as pink as a possum's nose, eyes possum blind [ . . . ], cable-knit jersey, knitted by his mother; tan trousers [and] tennis shoes' (p. 129) undercut his role as martyr. Similarly, Ossie's concern throughout the episode for Teresa suggests a more altruistic stance, but his effort to offer her warmth may simply be another attempt to play the hero. It is actually $\mathrm{Mr}$ Redknapp who seems more heroic. Overcoming his physical weakness, he climbs the tree, befriends Bike, and talks him into coming down. But, as we later learn, it is of himself and his World War I adventures that he has spoken.

Thus in Orchard Street, although the personal, the everyday, and commonality are interwoven with the universal, grandiose and symbolic, the former takes precedence over the latter, just as the qualities of altruism and responsibility, and an inclusive view acknowledge that, in the fullest sense of the term, socialism respects all humanity, including 
those who are personally or politically unsocial, ordinary, or deranged. It is a view that the adolescent Ossie approaches but does not fully achieve.

\section{Orchard Street's Framing Structures and New Zealand Politics 1984 to 1998}

In depicting mixed, antithetical sides, Gee holds them in balance, while the conflation of time settings, and of the personal and political contribute to a novel that stands integrated, inclusive and still against its destabilising energy, thus embodying his socialist beliefs. Adding to the novel's stability, the governing point of view, that of an adult Ossie going back in time to remember his childhood, and then moving forwards again towards a resolution, provides it with a frame.

Effectively comprising a prologue, the first two pages of Chapter 1 are set in a downtown Auckland square, and depict Ossie meeting Bike after 'more than 40 years' (p. 7), making the date about 1991 and their ages around fifty-four. What follows in the bulk of the novel, are the adult Ossie's memories of 1951, motivated by this meeting. Then, returning us to the downtown square, the final three pages of Chapter 13 form an epilogue. 1991 has an historical significance. It was the year of the watersiders' reunion when, as elderly men, they reminded one that youth's passion burns out in spite of Barnes' claim that 'never a white flag' should they raise (Barnes 1998, cover). The setting in the downtown square is ironic since, as we have seen, it was the location of the police attack on protesting unionists on 18 March 1951. Some forty years on, Ossie's and Bike's meeting in the fictional square is peaceful. Bike's juxtaposition against the square's statue of a Maori chief is also ironic. Recalling Molly McAlister's real sculpture of Kupe, the great Maori chief and explorer, the fictional version, once a warrior, now a statue, suggests that neither war nor peace last forever (Woodward 1983, unpaginated). Similarly, as he tells Ossie, Bike Pike in 1991, as manager of a supermarket, is an ironic reversal of the warring super power he once so briefly was.

Surrounding the frame provided by the prologue and epilogue is another less visible frame that of an older Ossie writing his novel. He records in the prologue: 'Since that meeting in 
the downtown square I've spent a lot of time sorting things out. Who was I, who was Bike, who was Teresa - and Eileen, Les, Mr Redknapp and the rest?' (p. 8). Then in the epilogue he reflects on his writing, noting that he will do what Dickens did, 'tie up the ends' (p. 135) and that, having 'showed [Teresa] this story a while ago', she has advised him: 'That's the way to end it' (p. 137). Aside from further rounding off the novel, the progression from Grey's romantic individualism to Dickens' socialism suggests the older Ossie's greater maturity and awareness of authorial technique.

The time lapse between the adult Ossie in 1991 and the older Ossie 'a lot of time' later brings the latter closer to the sixty-seven year old Gee who writes his novel in 1998. Their parallel is obvious: the older Gee and older Ossie record their memories of childhood during a post socialist era in New Zealand politics, in fact by writing the same novel. But where the older Ossie's novel has been motivated by his meeting with Bike in 1991, the older Gee's novel has apparently been motivated by the influence on New Zealand politics from 1984 on, of the New Right ideology of British Prime Minister, Margaret Thatcher, and American President, Ronald Reagan.

Gee, the pacifist, would undoubtedly have approved of the 1984 Labour Government's Prime Minister, David Lange, a liberal humanist, internationally recognised for his antinuclear stance in the 1985 Oxford Union debate. Indeed, because of Lange's stance, New Zealand was suspended from ANZUS in 1985, perhaps causing Gee to make an ironic connection to its pro-nuclear stance during the Cold War when ANZUS was originally formed. However, behind Lange, an elite group from cabinet, Treasury, the Reserve Bank, and the Business Roundtable pushed through radical reforms in economic and public policy, and in the state and business sectors. Driven by Roger Douglas (Minister of Finance), the reforms were often termed Rogernomics (after Reaganomics). Accordingly, with economic deregulation, government functions were cut, corporatized, privatised, or contracted out, and legislatively required to act as businesses, public assets were sold, laws were called to weaken the unions, and militant employers demanded wage cuts (Mein Smith 2005, pp. 209-11). 
From November 1990 to November 1999 the subsequent National government pursued Labour's market reforms and extended them to social policy. Gee would remember 1991 as the year of the Employment Contracts Act, the radical deregulation of the labour market, its adoption of individual employment contracts, and the drastic cuts in welfare, with many public institutions (such as post offices) being discontinued, and thousands of workers, wharfies included, losing their jobs (Mein Smith 2005, pp. 12-13). These events add to the resonance of Ossie's and Bike's reunion in 1991 in the fictional downtown square. That the reforms occurred with such speed, crusading zeal, and theoretical purity, led to comparisons to a blitzkrieg (Mein Smith 2005, p. 209). As several of those historians who recorded their memories of the 1951 National Government's lockout have commented, the decentralising policies of the 1984-1989 Labour Government demonstrated a similar mentality (see for example, Mein Smith 2005, and Andersen and Lee in Grant 2004). Apparently making identical connections, Gee seeks in Orchard Street to balance the politics not only of New Zealand's 1951 right wing National Government, but also of New Zealand's 1984-1999 new right Labour and National Governments.

\section{Conclusion}

The establishment of multiple frames contributes to the novel as an embodiment of the balanced whole. From the outer frame of the older author in 1998, to the frame of the older Ossie as Gee's ironic parallel, to the frame formed by Ossie's and Bike's meeting in 1991, the novel progresses inwards through a fusion of personal and political historical contexts to the circular structure of Orchard Street, and finally to the central consciousness of the adolescent Ossie who seeks to resolve the conflicts within and around him. Paradoxically, then, the concentrically shaped novel reflects the unsocial, unstable and imperfect street while being in itself integrated, stable, perfectly formed, and complete. At the same time, like each of its characters, the novel is interwoven with the larger collective: the external texts and contexts which inform it, and which it, in turn, informs. 
Thus, in its substance, structure and inter-contextualization, Orchard Street embodies Gee's vision of socialism in a politically conservative period. The radical departure from writing fantasy in order to write historical realism allows Gee more fully and explicitly to explore his political beliefs. Similarly, his portrayal of a first person protagonist who appears in the novel as an adult and an adolescent allows him to create a realistically imperfect but likeable character who is more complex, rounded and reflective than those in his fantasy novels and the earlier historical novels. Finally, then, content and form are perfectly united with Gee's socialistic vision in Orchard Street.

\section{References}

Andersen, Bill (2004) 'Unionism and the '51 Lockout.' In D. Grant (ed) The Big Blue: Snapshots of the 1951 Waterfront Lockout. Christchurch: Canterbury University Press, pp. $115-18$.

Anonymous (1951) 'Sid's Trip to the Moon.' Wellington: Turnbull Library collection. (Taken from his personal files, this poem was read by Gee to the author during a telephone conversation.)

Author's Interviews with Two Elderly Residents of Newington Road, Auckland (2005, unpublished).

Bailey, Rona (2004) 'Telling the World "the Other Side of the Story."' In D. Grant (ed) The Big Blue: Snapshots of the 1951 Waterfront Lockout. Christchurch: Canterbury University Press, pp. 38-44.

Barnes, Jock (1998) Never a White Flag. Wellington: Victoria University Press.

Barrowman, Rachel (2015) Maurice Gee: Life and Work. Wellington: Victoria University Press.

Bassett, Michael (1972) Confrontation '51: The Waterfront Dispute. Wellington: A.H. \& A.W. Reed.

Carlyon, Jenny and Morrow, Diana (2013) Changing Times: New Zealand since 1945. Auckland: Auckland University Press. 
Clark, Louise (2013) 'Writing Horizontally and Vertically in The World Around the Corner and Hostel Girl.' In E. Hale (ed) Maurice Gee a Literary Companion: The Fiction for Young Readers. Dunedin: Otago University Press, pp. 123-46.

Gee, Maurice (March 1977) 'Beginnings.' Islands 5 (3): 284-92.

Gee, Maurice (2002) 'Creeks and Kitchens: Margaret Mahy Lecture'. The Inside Story: Year Book. Auckland: Storylines Children's Literature Foundation of New Zealand, 11-25.

Gee, Maurice (1998) Orchard Street. Auckland: Viking.

Hebley, Diane (2013) 'The Good, the Bad - and Ironic Reversals: Moralscape in Gee's realist historical quintet for young readers.' In E. Hale (ed) Maurice Gee a Literary Companion: The Fiction for Young Readers. Dunedin: Otago University Press, pp. 55-82.

Hunt, Graeme (2004) Black Prince: The Biography of Fintan Patrick Walsh. Auckland: Penguin Books.

Jackson, Anna; Miles, Geoffrey; Ricketts, Harry; Schaefer, Tatjana; and Walls, Kathryn (2011) A Made-up Place: New Zealand in Young Adult Fiction. Wellington: Victoria University Press. Laurence, Richard (1883) The Book of Enoch the Prophet, Chapter LIX, Verse 8. Retrieved 2016, January 14 from http://sacred-texts.com/bib/bep/bep04.htm.

Lee, Sandra (2204) 'All in the Family.' In D. Grant (ed) The Big Blue: Snapshots of the 1951 Waterfront Lockout. Christchurch: Canterbury University Press, pp. 124-30.

Manhire, Bill (1986) Maurice Gee. Auckland: Oxford University Press.

Matthewson, Claire (1986) From Subject to Device: History as Myth in Action. The Evolution of Event from Mythic Processes as Revealed in Waterfront Dispute Fiction. Doctoral thesis, University of Otago, Dunedin.

Mein Smith, Philippa (2005) A Concise History of New Zealand. Melbourne: Cambridge University Press.

Oliver, William and Williams, Bridget (eds.) (1981) The Oxford History of New Zealand. Wellington: Oxford University Press.

Phillips, Jock (2004) 'The '51 Lockout: The Last Hurrah.' In D. Grant (ed) The Big Blue: Snapshots of the 1951 Waterfront Lockout. Christchurch: Canterbury University Press, pp. 146-50.

Scott, Dick (1954) 151 days. Auckland: Southern Cross. 
Scott, Dick (2004) Dick Scott: A Radical Writer's Life. Auckland: Reed Publishing. Scott, Dick (2004) 'The Propaganda War.' In D. Grant (ed) The Big Blue: Snapshots of the 1951 Waterfront Lockout. Christchurch: Canterbury University Press, pp. 30-37.

Van Rij, Vivien (2013) 'Patterns of Exchange: Setting, Hero, Villain and Child'. In E. Hale (ed) Maurice Gee a Literary Companion: The Fiction for Young Readers. Dunedin: Otago University Press, pp. 147-61.

Van Rij, Vivien (2008) The Pursuit of Wholeness in Maurice Gee's Fiction for Children.

Doctoral thesis, Victoria University of Wellington.

Woodward, Robin (Autumn 1983) 'The Sculpture of Molly Macalister.' Art New Zealand 26.

Retrieved January 14, 2016 from http://www.art-newzealand.com/Issues21to30/molly.htm. Yska, Redmer (2004) 'Spies, Lies and Red Herrings.' In D. Grant (ed) The Big Blue: Snapshots of the 1951 Waterfront Lockout. Christchurch: Canterbury University Press, pp. 22-29.

\section{Biographical Note}

Vivien van Rij is a lecturer in English in the Faculty of Education, Victoria University of Wellington, New Zealand where she teaches literacy and children's literature on under-graduate and post-graduate courses. Vivien's doctoral thesis was on Maurice Gee's novels for children, and she has published widely on these and on New Zealand's School Journal. Vivien has a particular interest in the pedagogical and literary qualities of texts. She has presented at many international conferences and is currently working on an article on Jack Lasenby's Traveller's Quartet. 